\title{
Comparison between Dexmedetomidine and Glyceryl Trinitrate in Improving Quality of the Operative Field During Functional Endoscopic Sinus Surgery
}

\author{
Samer B. Kamel ${ }^{\text {a }}$, Ahmed S. Elkady ${ }^{a}$, Mohsen M. Abd El-Razek ${ }^{\mathrm{a}}$, Mohammed H. Abd \\ El-Rahman ${ }^{\mathrm{b}}$, Omar S. Abd Al Maksoud ${ }^{\mathrm{a}}$
}

\begin{abstract}
Department of otorhinolaryngology,

Faculty of Medicine Benha

University, Egypt.

${ }^{\mathrm{b}}$ Department of Anesthesia,

Faculty of Medicine Benha

University, Egypt
\end{abstract}

Correspondence to:

Omar S. Abd Al Maksoud,

Department of

otorhinolaryngology,

Faculty of Medicine Benha

University, Egypt.

Email:

omarselimdr@gmail.com

Received: 9 August 2020

Accepted: 7 August 2021

\section{Abstract}

Background: Functional endoscopic sinus surgery [FESS] is a wellestablished therapeutic option for intractable CRS. In case of major bleeding, risk of complications such as meningitis, blindness, intracranial injury, cerebrospinal fluid $[\mathrm{CSF}]$ leakage and the duration of surgery increase. Aim of work: The present work aims to compare between the efficacy of dexmedetomidine and glyceryl trinitrate in inducing controlled hypotension to improve the quality of the operative field during FESS under general anesthesia. Materials and Methods: In our study, the number of patients was 40 which were divided randomly into two groups: (a) Glyceryl trinitrate group: twenty patients received Glyceryl trinitrate (GTN group). (Dexmedetomidin group: twenty patients received Dexmedetomidine (DEX group). Results: It was confirmed that dexmedetomidine causes significant stable hemodynamics, excellent surgical field and significant surgeon satisfaction compared to glyceryl trinitrate. It also causes sedation effect so less extra doses of fentanyl were used.

Conclusion: We concluded that during ambulatory FESS, dexmedetomidine is more effective than glyceryl trinitrate for providing controlled hypotension and rendering an excellent surgical field with higher surgeon's satisfaction score and lesser analgesic requirement without major hemodynamic alteration.

Keywords: Functional endoscopic sinus surgery, bleeding and hypotension.

\section{Introduction}

As chronic rhinosinusitis has a significant negative impact on quality of life, treatment is typically required [1].In most cases, chronic rhinosinusitis can be managed through pharmacologic means; however, some individuals do not respond to such intervention and require surgery [2]. Functional endoscopic sinus surgery [FESS] is a well-established therapeutic 
option for intractable CRS and other indications[3].

In case of major bleeding, risk of complications such as meningitis, blindness, intracranial injury, cerebrospinal fluid $[\mathrm{CSF}]$ leakage and the duration of surgery increase [4].

Reduction of the bleeding and improvement of surgical conditions are essential to increase the visibility in the operation field during FESS and to avoid the complications such as orbital, skull base and internal carotid artery injury [5].

Dexmedetomidine, is a selective, shortacting, central $\alpha 2$-adrenergic agonist and is characterized by dose dependent decrease in arterial blood pressure, heart rate [HR], cardiac output and norepinephrine release [6].

The Glyceryl trinitrate [GTN] biotransformation pathway produces nitric oxide and contributes directly to its vasodilating effect [7].

\section{Materials and Methods}

This prospective study was performed from January 2017 to January 2018.

Approval of Ethics Committee in Faculty of Medicine; Benha University was taken before conduction of the study.
Informed consent was obtained from all participating patients before their inclusion at the outpatient clinic and another consent before undergoing FESS.

\section{Patients:}

This study was carried out on 40 patients that was selected from the Otorhinolaryngology outpatient clinic of Benha University Hospital .

The criteria of selection was carried on those who complain of symptoms of chronic sinusitis and nasal obstruction due to sinonasal polyposis of different grades that is refractory to medical treatment and defined by their clinical history, physical examination and radiographic findings.

\section{Inclusion criteria:}

Patients complaining of signs of bilateral chronic and/or recurrent rhinosinusitis and nasal obstruction from sinonasal polyposis of different grades that is refractory to medical management and defined by their clinical history, physical examination and radiographic findings.

\section{Exclusion criteria}

1. Patients with coagulopathies.

2. Patients with a known systemic disease requiring the use of anticoagulants.

3. Patients with a history of previous FESS. 


\section{Study design:}

Patients was divided randomly in to two groups:

a) Glyceyl trinitrate group: twenty patients received Glyceryl trinitrate (GTN group).

b) Dexmedetomidine group: twenty patients received Dexmedetomidine (DEX group).

The 2 groups of patients were treated identically in all aspects.

During their intraoperative and postoperative follow up, the predefined outcome measures were recorded and the findings were compared between the two groups.

\section{Study procedure:}

All the patients were subjected to the followings:

\section{A-Pre-operative Assessment:}

All patients were assessed pre-operatively for the extent of chronic sinusitis which is resistant to medical treatment diagnosed clinically and radiologically or sinonasal polyposis with ASA I and ASA II physical status.

American Society of Anestheiologists (ASA), physical status classification:

I Healthy patient.
II Mild systemic disease- no functional limitations.

III severe systemic disease-difinite functional limitation .

IV Severe systemic disease that is constant threat to life.

$\mathrm{V}$ Moribund patient unlike to survive $24 \mathrm{~h}$ with or without operation.

B- Anasthetic technique:

All the patients underwent FESS using mucosal sparing technique and were divided randomely into two groups:

a) The patients of the glyceryl trinitrate group received an infusion at the level of $25-200 \mu \mathrm{g} / \mathrm{min}$, according to the response diluted in $0.9 \%$ saline which will start after sterilization and positioning of the patients.

b) The patients of the dexmedetomidine group received a loading dose of $1 \mu \mathrm{g} / \mathrm{kg}$ dexmedetomidine diluted in $100 \mathrm{ml} 0.9 \%$ saline over 10 minutes just before induction of anesthesia, followed by continuous infusion of $0.2-0.7 \mu \mathrm{g} / \mathrm{kg} / \mathrm{h}$.

\section{All the patients were subjected to the followings:}

All the patients were pre oxygenated and premedicated with intravenous midazolam $0.05 \mathrm{mg} / \mathrm{kg}$ and Fentanyl $2 \mu \mathrm{g} / \mathrm{kg}$.

Induction of anesthesia was accomplished with $2 \mathrm{mg} / \mathrm{kg}$ intravenous Propofol $2 \%$. 
Endotracheal intubation was done with suitable - sized cuffed tube.

Normocapnic mechanical ventilation was performed and the anesthesia was maintained with sevoflurane 1-3\% and muscle relaxation when needed was done.

After induction and intubation, all patients were laid in an approximately $30^{\circ}$ reverse Trendlenburg position.

A standard dose of adrenaline (1:200 000 adrenaline) was packed in the nasal cavity.

The quality of the surgical field was estimated using the category scale that was described by Fromme 1986 (8).

0 : No bleeding.

1: Slight bleeding, no suctioning of blood required.

2: Slight bleeding occasional suctioning required. Surgical field not threatened.

3: Slight bleeding frequent suctioning required. Bleeding threatens surgical field a few seconds after suction is removed.

4: Moderate bleeding frequent suctioning required. Bleeding threatens surgical field directly after suction is removed.

5: Severe bleeding constant suctioning required. Bleeding appears faster than can be removed by suction. Surgical field severely threatened and surgery not possible.

The ideal values of category scale of surgical field were determined to be 2-3.

Monitoring of the mean arterial blood pressure (MAP) and the heart rate (H-R) was recorded at regular intervals of time.

\section{C- Outcome measures:}

a-assessment of quality of the operative field.

b-assessment of quantity of blood loss during the operation.

c- assessment of the mean arterial blood pressure (MAP).

d-assessment of the heart rate (HR).

\section{Results}

This study included a total of forty patients with chronic rhino-sinusitis (CRS) refractory to medical treatment or sinonasal polyposis presented for us in outpatient clinic and fulfilling the inclusion criteria in the absence of any of the exclusion criteria All patients underwent Functional Endoscopic Sinus Surgery (FESS) after receiving medical treatment and experienced no improvement. 
Classification of cases:

a. According to age, sex, weight and ASA score
*The age in our study ranged from 22 till 48 years with mean value $33.10 \pm 7.60$ (Table 1)

Table (1):

\begin{tabular}{lll}
\hline & & Total no. $=\mathbf{4 0}$ \\
Age $($ years $)$ & Mean \pm SD & $33.10 \pm 7.60$ \\
Range & Female & $22-48$ \\
Weight & Male & $18(45.0 \%)$ \\
& Mean \pm SD & $22(55.0 \%)$ \\
ASA Score & Range & $77.20 \pm 12.16$ \\
& I & $57-95$ \\
& II & $26(65.0 \%)$ \\
\hline
\end{tabular}

Table 2: Classification according to the quality of the surgical field.

In the analysis of the quality of surgical field during FESS surgery, their was no significant difference between both groups of drugs during all times of surgery as both groups provide the surgeon with good quality of the surgical field

\begin{tabular}{|c|c|c|c|c|c|c|}
\hline Scale of surgical field $(0-5)$ & & $\begin{array}{l}\text { Group A } \\
\text { No. }=20 \\
\end{array}$ & $\begin{array}{l}\text { Group B } \\
\text { No. }=\mathbf{2 0} \\
\end{array}$ & Test value• & $\begin{array}{l}P \text { - } \\
\text { value }\end{array}$ & Sig. \\
\hline \multirow[t]{2}{*}{15 mins of hypotension } & Mean \pm SD & $2.2 \pm 0.41$ & $2.1 \pm 0.31$ & 0.872 & 0.389 & $\mathrm{NS}$ \\
\hline & Range & $2-3$ & $2-3$ & & & \\
\hline \multirow[t]{2}{*}{30 mins of hypotension } & Mean \pm SD & $1.9 \pm 0.21$ & $1.8 \pm 0.25$ & 1.378 & 0.176 & NS \\
\hline & Range & $1.5-2$ & $1.5-2$ & & & \\
\hline \multirow[t]{2}{*}{45 mins of hypotension } & Mean \pm SD & $\begin{array}{l}1.85 \pm \\
0.31\end{array}$ & $\begin{array}{l}1.75 \pm \\
0.32\end{array}$ & 1.000 & 0.324 & NS \\
\hline & Range & $1.25-2$ & $1.25-2$ & & & \\
\hline \multirow[t]{2}{*}{60 mins of hypotension } & Mean \pm SD & $1.8 \pm 0.41$ & $1.6 \pm 0.45$ & 1.474 & 0.149 & NS \\
\hline & Range & $1-2$ & $1-2$ & & & \\
\hline \multirow[t]{2}{*}{75 mins of hypotension } & Mean \pm SD & $2 \pm 0$ & $2 \pm 0$ & - & - & - \\
\hline & Range & $2-2$ & $2-2$ & & & \\
\hline
\end{tabular}

Baseline values of MAP were comparable in both groups. On comparison, there was a significant reduction in MAP compared with baseline values after induction of However, in the GTN group a rise in MAP was noticed before extubation, followed by a significant reduction at $5 \mathrm{~min}$ after extubation. The studied drugs reached the desired MAP (55-65 $\mathrm{mmHg})$ with significant differences detected between anesthesia and during the hypotensive period in both groups. This reduction extended until extubation in the DEX group.

both groups during the hypotensive period from 30 up to $75 \mathrm{~min}$ and extended until extubation, with the lowest values observed in the DEX group followed by the GTN group in almost all times. 
Table 3: Classification according to mean arterial blood pressure (MAP)

\begin{tabular}{|c|c|c|c|c|c|c|}
\hline MAP & & $\begin{array}{l}\text { Group A } \\
\mathrm{No}_{0 .}=20\end{array}$ & $\begin{array}{l}\text { Group B } \\
\mathrm{No}_{0}=20\end{array}$ & Test value• & P-value & Sig \\
\hline \multirow[t]{2}{*}{ Basal } & Mean \pm SD & $93.1 \pm 12.57$ & $97.4 \pm 4.86$ & -1.427 & 0.162 & NS \\
\hline & Range & $81-121$ & $92-106$ & & & \\
\hline \multirow[t]{2}{*}{ After induction } & Mean \pm SD & $89 \pm 12.61$ & $94.5 \pm 7.99$ & -1.648 & 0.108 & NS \\
\hline & Range & $75-112$ & $81-105$ & & & \\
\hline \multirow[t]{2}{*}{ After intubation } & Mean \pm SD & $100.2 \pm 17.01$ & $93.1 \pm 10.77$ & 1.577 & 0.123 & NS \\
\hline & Range & $80-132$ & $77-107$ & & & \\
\hline \multirow[t]{2}{*}{ After 15 min } & Mean \pm SD & $68.9 \pm 5.51$ & $69.5 \pm 7.32$ & -0.293 & 0.771 & NS \\
\hline & Range & $61-78$ & $58-79$ & & & \\
\hline \multirow[t]{2}{*}{ After 30 min } & Mean \pm SD & $63.70 \pm 4.73$ & $60.60 \pm 3.41$ & 2.379 & 0.022 & $\mathrm{~S}$ \\
\hline & Range & $58-72$ & $55-65$ & & & \\
\hline \multirow[t]{2}{*}{ After 45 min } & Mean \pm SD & $60.90 \pm 2.95$ & $57.80 \pm 4.15$ & 2.722 & 0.010 & $S$ \\
\hline & Range & $58-66$ & $52-64$ & & & \\
\hline \multirow[t]{2}{*}{ After $60 \mathrm{~min}$} & Mean \pm SD & $63.85 \pm 5.22$ & $60.30 \pm 5.45$ & 2.103 & 0.042 & $S$ \\
\hline & Range & $57-73$ & $53-71$ & & & \\
\hline \multirow[t]{2}{*}{ After $75 \mathrm{~min}$} & Mean \pm SD & $66.30 \pm 4.70$ & $61.90 \pm 6.41$ & 2.474 & 0.018 & $\mathrm{~S}$ \\
\hline & Range & $59-74$ & $52-73$ & & & \\
\hline \multirow[t]{2}{*}{ Before extubation } & Mean \pm SD & $96.1 \pm 8.84$ & $88.9 \pm 6.33$ & 2.960 & 0.005 & HS \\
\hline & Range & $86-114$ & $81-101$ & & & \\
\hline \multirow[t]{2}{*}{5 min after extubation } & Mean \pm SD & $95.8 \pm 8.75$ & $91.4 \pm 9.94$ & 1.486 & 0.146 & NS \\
\hline & Range & $86-114$ & $79-107$ & & & \\
\hline
\end{tabular}

In the analysis of HR, significant difference was detected between the groups at 45 and $75 \mathrm{~min}$ of the hypotensive period, before extubation, and at 5 min after extubation (with $\mathrm{P}$ values $0.010, \quad 0.039, \quad<0.034$, and $<0.041$, respectively), with slower and more steady rate observed in the DEX group. Intergroup comparison showed a significant reduction in HR in both groups after induction and throughout the hypotensive period in comparison with the basal HR. This significant reduction continued until extubation and 5 min after extubation in the DEX group. However, it showed significant increase in the GTN group at those two times.

Table 4: Classification according to the analysis of heart rate (HR)

\begin{tabular}{llllll}
\hline Heart rate & $\begin{array}{l}\text { Group A } \\
\text { Mean } \pm \text { SD }\end{array}$ & $\begin{array}{l}\text { Group B } \\
\text { Mean } \pm \text { SD }\end{array}$ & Test value• & $\begin{array}{l}\text { P- } \\
\text { value }\end{array}$ & Sig. \\
\hline Basal & $87 \pm 3.2$ & $86 \pm 2.9$ & -1.036 & 0.307 & $\mathrm{NS}$ \\
After induction & $76 \pm 4.15$ & $78 \pm 3.17$ & 1.713 & 0.095 & $\mathrm{NS}$ \\
After intubation & $84 \pm 2.3$ & $85 \pm 2.8$ & 1.234 & 0.225 & $\mathrm{NS}$ \\
After 15 mins & $80 \pm 4.4$ & $77 \pm 5.3$ & -1.948 & 0.059 & $\mathrm{NS}$ \\
After 30 mins & $72 \pm 2.5$ & $70 \pm 3.7$ & -2.003 & 0.052 & $\mathrm{NS}$ \\
After 45 mins & $74 \pm 3.2$ & $71 \pm 3.8$ & -2.701 & 0.010 & $\mathrm{~S}$ \\
After 60 mins & $71 \pm 4.3$ & $68 \pm 4.6$ & -2.131 & 0.039 & $\mathrm{~S}$ \\
After 75 mins & $72 \pm 3.6$ & $69 \pm 4.9$ & -2.207 & 0.034 & $\mathrm{~S}$ \\
Before extubation & $83 \pm 4.35$ & $80 \pm 4.59$ & -2.122 & 0.041 & $\mathrm{~S}$ \\
5 min after extubation & $90 \pm 4.51$ & $87 \pm 4.37$ & -2.136 & 0.039 & $\mathrm{~S}$ \\
\hline
\end{tabular}


Table 5: Classification according to surgical time, anesthesia time and blood loss: There was no significant differences between the surgical time, anesthesia time and blood loss between both groups.

\begin{tabular}{|c|c|c|c|c|c|c|}
\hline & & $\begin{array}{l}\text { Group A } \\
\text { No. }=20 \\
\end{array}$ & $\begin{array}{l}\text { Group B } \\
\text { No. }=20 \\
\end{array}$ & $\begin{array}{l}\text { Test } \\
\text { value• }\end{array}$ & $\begin{array}{l}\text { P- } \\
\text { value }\end{array}$ & Sig. \\
\hline \multirow[t]{2}{*}{ Surgical Time (min) } & $\begin{array}{l}\text { Mean } \pm \\
\text { SD }\end{array}$ & $90 \pm 4.21$ & $91.6 \pm 4.24$ & -1.199 & 0.238 & NS \\
\hline & Range & $85-97$ & $86-98$ & & & \\
\hline \multirow[t]{2}{*}{ Anesthesia time (min) } & $\begin{array}{l}\text { Mean } \pm \\
\text { SD }\end{array}$ & $99.5 \pm 3.87$ & $100.6 \pm 4.06$ & -0.877 & 0.386 & NS \\
\hline & Range & $95-106$ & $95-107$ & & & \\
\hline \multirow[t]{2}{*}{ Blood Loss (min) } & $\begin{array}{l}\text { Mean } \pm \\
\text { SD }\end{array}$ & $209 \pm 26.14$ & $212 \pm 38.61$ & -0.288 & 0.775 & NS \\
\hline & Range & $170-250$ & $150-270$ & & & \\
\hline \multirow[t]{2}{*}{$\begin{array}{l}\text { Time to restore basal } \\
\text { MAP (min) }\end{array}$} & $\begin{array}{l}\text { Mean } \pm \\
\text { SD }\end{array}$ & $7.6 \pm 2.01$ & $8.3 \pm 1.84$ & -1.149 & 0.258 & NS \\
\hline & Range & $4-10$ & $5-11$ & & & \\
\hline
\end{tabular}

Table 6: Classification according to using other drugs: Significant difference was noticed in the using fentanyl in the GTN group more than the DEX group. There was no significant difference between the two groups in using other drugs.

\begin{tabular}{llllll}
\hline & $\begin{array}{l}\text { Group A } \\
\text { No. (\%) }\end{array}$ & $\begin{array}{l}\text { Group B } \\
\text { No. }(\%)\end{array}$ & Test value & P-value & Sig. \\
\hline Fentanyl & $11(55.0 \%)$ & $3(15.0 \%)$ & 7.033 & 0.008 & HS \\
Atropine & $3(15.0 \%)$ & $2(10.0 \%)$ & 0.229 & 0.632 & NS \\
Ephedrine & $6(30.0 \%)$ & $6(30.0 \%)$ & 0.000 & 1.000 & NS \\
\hline
\end{tabular}

\section{Discussion}

In this prospective study, dexmedetomidine or GTN was used to induce controlled hypotension to provide a good surgical field. The results revealed that the two drugs reached the desired MAP (55-65 mmHg) with significant differences detected during the hypotensive period from 30 up to $75 \mathrm{~min}$ and extended until extubation with the lowest values in the DEX group and lastly the GTN group in almost all times.

For HR, significant reduction in both groups was detected during the hypotensive period; this reduction continued until extubation and 5 min after extubation in the DEX group only.

However, it showed a significant increase in the GTN group at those two times and slower and steadier rate in the DEX group. Intraoperative blood loss and quality of the surgical field during the hypotensive period were comparable in both groups with no significant differences.

The target cMAP between 55 and 65 $\mathrm{mmHg}$ was decided after revising previous studies in which metabolic and hormonal responses were investigated in patients who were subjected to induced 
hypotension to provide bloodless field without the hazard of tissue ischemia.

Although the two drugs were effective in achieving the target MAP, lowering the $\mathrm{HR}$, and ensuring good surgical condition during the procedure, the hemodynamic profile of dexmedetomidine was steadier, which can be attributed to the known sympatholytic effect of $\alpha-2$ agonists.

The $\alpha-2$ receptors are involved in regulating the autonomic and cardiovascular systems; thus, the receptors on sympathetic terminal inhibit norepinephrine release and those located on blood vessels mediate vasoconstriction [9].

At lower doses, DEX is predominantly sympatholytic. DEX, on binding to $\alpha-2$ receptors, reduces the sympathetic outflow and augments cardiac vagal activity, thus resulting in a decreased $\mathrm{HR}$ and cardiac output [10]

It causes analgesia and sympatholysis and has sedative, anxiolytic, and hypnotic effects [11].

As regards GTN, it has shown that it reduced bleeding and improved surgical view quality with MAP $50-60 \mathrm{mmHg}$ during endoscopic nasal surgery [12].

However, it was found that a continuous infusion of DEX is effective in minimizing blood loss and maintaining superior hemodynamics as compared with GTN in posterior fixation spine surgeries [13].
GTN produces its hypotensive action by liberating nitric oxide, which has a halflife of $0.1 \mathrm{~s}$ [14]. Whereas DEX acts by selectively binding to $\alpha-2$ receptors with great affinity [15].

This could explain our findings, which is in agreement with those of in which longer time to restore the baseline MAP and more hemodynamic stability were observed during extubation in the DEX group compared with the GTN group even after the hypotensive drugs were stopped [16] . On evaluating the intraoperative fentanyl and first postoperative analgesic request, this study showed that fentanyl was significantly lower, together with longer time to require postoperative analgesia, in the DEX group compared with the GTN group.

In accordance with our results, several studies have demonstrated the analgesic properties of both drugs as in [17]. Whereas, others showed that perioperative use of dexmedetomidine was associated with a significant reduction in the consumption of fentanyl in a dosedependent manner as in these studies [18] and [19].

This can be explained by the sedative and analgesic sparing effects of dexmedetomidine through central actions in the locus coeruleus and in the dorsal horn of the spinal cord [20]. 
In conclusion, dexmedetomidine provided more stable hemodynamics, greater visual quality of the surgical field and superior recovery profile with less post-operative complications compared to glyceryl trinitrate when used in patients underwent Functional endoscopic sinus surgery (FESS) under general anesthesia.

As a result, we believe that in Functional endoscopic sinus surgeries, dexmedetomidine is a good alternative to glyceryl trinitrate.

The effect of the studied drugs on the release of catecholamine and other stress hormones either intraoperatively or postoperatively was not investigated.

\section{References}

[1] Khalid AN,Quraishi SA, Kennedy DW, Longterm quality of life measures after functional endoscopic sinus surgery. Am JRhinol; vol. 18, pp. 131-136, 2004.

[2] Welch KC, StankiewiczJA. A contemporary review of endoscopic sinus surgery: techniques, tools, and outcomes. Laryngoscope; vol. 119, pp. 2258-2268, 2009.

[3] Georgalas C, Cornet M, Adriaensen G. Evidence-based surgery for chronicrhinosinusitis with and without nasal polyps. CurrAllergyAsthmaRep;vol. 2014, pp. 14-427, 2014

[4] Jahanshahi J, Hashemian F, Pariza S. Effect of topical tranexamic acid on bleeding and quality of surgical field during functional endoscopic sinus surgery in patients with chronic rhinosinusitis: atriple blind randomized clinical trial. PLos One; vol. 9( 8), pp. 1 04-477, 2014.
[5] Karabayirli S,SerifeUgur K,Irem R. Surgical conditions during FESS ; comparison of dexmedetomidine and remifentanil, 2015.

[6] Richa F, YazigA,Sleilaty G . Comparison between dexmedetomidine and remifentanil for controlled hypotension during tympanoplasty. Eur J Anaesthesiol; vol. 25,pp.369-374, 2008.

[7] Hashimoto S, Kobayashi A. Clinical pharmacokinetics pharmacokinetics of glyceryltrinitrate and its metabolites. Clincalpharmacokinet; vol. 42, pp. 205-221, 2003.

[8] Fromme GA, MacKenzie RA, Gould AB, Lund BA, Offord KP. Controlled hypotension for orthognathic surgery. Anesthesia and Analgesia 1986;65(6):683-6.

[9] Mikhail MS,.Thangathurai D,.Thaker KB. Echocardiographic assessment ofcoronary blood flow velocity during controlled hypotensive anesthesia with nitroglycerin, Journal of Cardiothoracic and vascular Anesthesia;vol. 14, pp. 565-70, 2000.

[10] Aboushanab OH, El-ShaarawyAM. A comparative study between magnesium sulfate and dexmedetomidine for deliberate hypotension during middle ear surgery. Egypt $\mathbf{J}$ Anaesth 2011; 27:227-232.

[11]Seyrek M, Halici Z, YildizO,Ulusoy HB. Interaction between dexmedetomidine and $\alpha$ adrenergic receptors: emphasis on vascular actions.JCardiothoracVascAnesth 2011; 25:856-862.

[12] Cincikas D, Ivaskevicius J. Application of controlled arterial hypotension in endoscopic rhinosurgery. Medicina (Kaunas) 2003; 39:852859.

[13] Jamaliya RH, Chinnachamy R, Maliwad J, Deshmukh VP, Shah BJ, Chadha IA. The efficacy and hemodynamic response to dexmedetomidineas a hypotensive agent in 
posterior fi xation surgery following traumatic spine injury. J AnaesthesiolClinPharmacol 2014; 30:203-207.

[14]Kelm M, Schrader J. Control of coronary vascular tone by nitric oxide. Circ Res 1990; 66:1561-1575.

[15] Bhana N, Goa KL, McClellan KJ.Dexmedetomidine. Drugs 2000; 59:263268.

[16] Jamaliya RH, Chinnachamy R, Maliwad J, Deshmukh VP, Shah BJ, Chadha IA. The efficacy and hemodynamic response to dexmedetomidineas a hypotensive agent in posterior fi xation surgery following traumatic spine injury. J AnaesthesiolClinPharmacol 2014; 30:203-207.

[17] Dubé L, Granry JC. The therapeutic use of magnesium in anesthesiology, intensive care and emergency medicine: a review. Can J Anaesth 2003; 50:732-746.

[18] Ayoglu H, Yapakci O, Ugur MB, Uzun L, Altunkaya H, Ozer Y, et al. Effectiveness of dexmedetomidine in reducing bleeding during septoplastyandtympanoplasty operations. J ClinAnesth 2008; 20:437-441.

[19] Gertler R, Brown HC, Mitchell DH, Silvius EN. Dexmedetomidine: a novel sedativeanalgesic agent. Proc (BaylUniv Med Cent) 2001; 14:13-21.

[20]Arpino PA, Kalafatas K, Thompson BT. Feasibility of dexmedetomidine in facilitating extubation in the intensive care unit. J Clin Pharm Ther 2008; 33:25-30.

To cite this article: Samer B. Kamel, Ahmed S. Elkady, Mohsen M. Abd El-Razek, Mohammed H. Abd El-Rahman, Omar S. Abd Al Maksoud. Comparison between Dexmedetomidine and Glyceryl Trinitrate in Improving Quality of the Operative Field During Functional Endoscopic Sinus Surgery. BMFJ 2021; 38(3):881- 890. DOI: 10.21608/bmfj.2021.38606.1302 